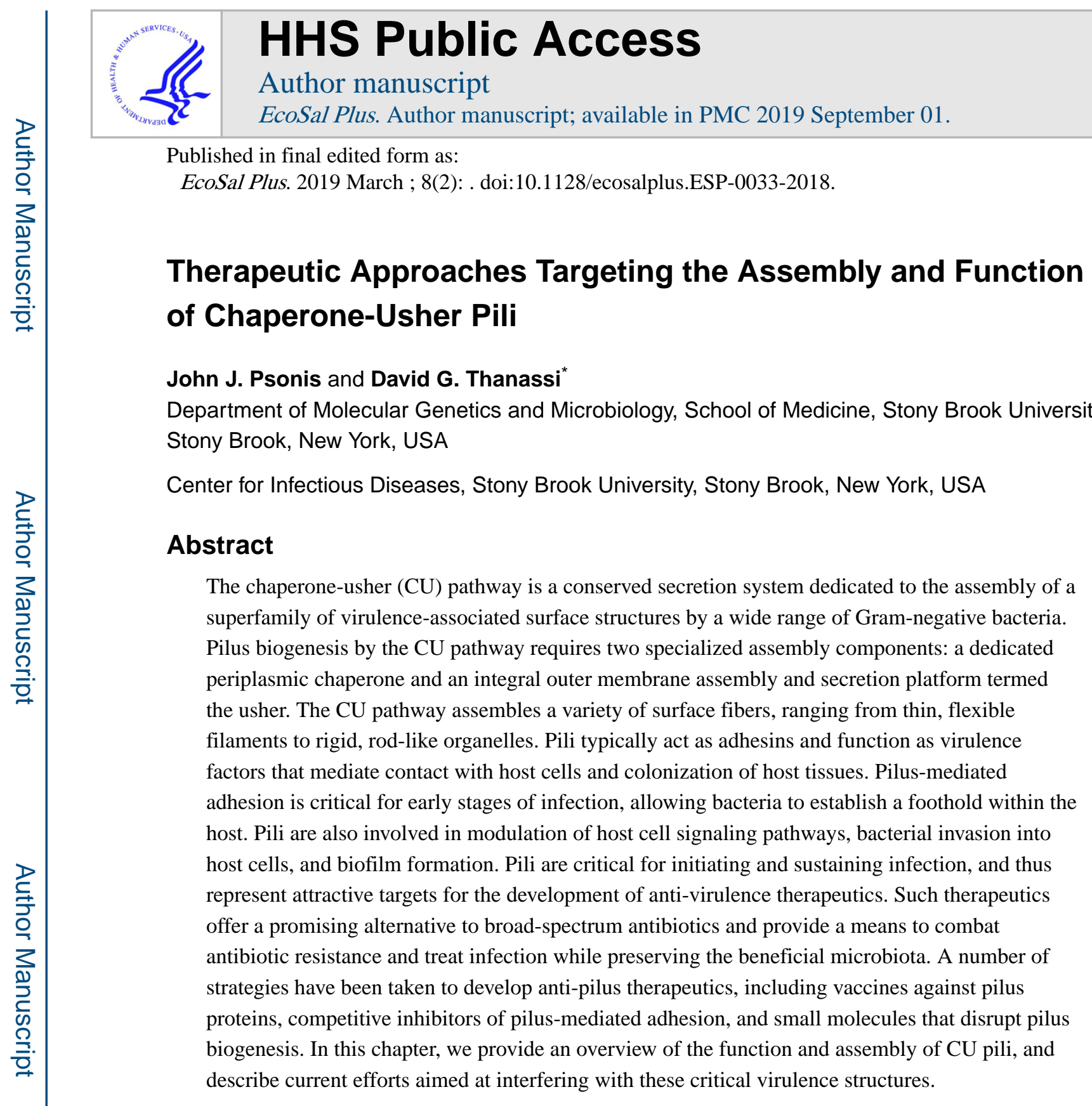

\title{
Introduction
}

The chaperone-usher (CU) pathway is dedicated to the biogenesis of surface structures termed pili or fimbriae that play indispensable roles in the pathogenesis of a wide range of bacteria (1-4). Pili are hair-like fibers composed of multiple different subunit proteins. They are typically involved in adhesion, allowing bacteria to establish a foothold within the host. Following attachment, pili modulate host-cell signaling pathways, promote or inhibit host cell invasion, and mediate bacterial-bacterial interactions leading to formation of community structures such as biofilms $(5,6)$. Gram-negative bacteria express multiple $\mathrm{CU}$ pili that contribute to their ability to colonize diverse environmental niches $(1,7-10)$. Pili thus

\footnotetext{
*Corresponding author: David G. Thanassi, david.thanassi@ stonybrook.edu.
} 
function at the host-pathogen interface both to initiate and sustain infection and represent attractive therapeutic targets.

\section{Pilus Function}

The most extensively characterized CU pili are type 1 pili, found in members of the Enterobacteriaceae, and P Pili, found in uropathogenic Escherichia coli (UPEC). Both pili are key virulence factors for UPEC colonization of the urinary tract and the establishment of urinary tract infections (UTI) (Fig. 1). Type 1 pili bind to mannosylated proteins in the bladder, leading to cystitis, and $\mathrm{P}$ pili bind to di-galactose-containing moieties in kidney glycolipids, leading to pyelonephritis (11-13). Bacterial binding via type 1 pili also activates host cell pathways that lead to actin cytoskeletal rearrangements and subsequent bacterial invasion into the host cells via a zipper-like mechanism $(14,15)$. Type 1 pili contribute to the formation of extracellular biofilms (16), as well as intracellular biofilm-like communities (IBCs) by UPEC during bladder infection (Fig. 1) (17). Bacteria within these IBCs are protected from antibiotics and immune surveillance $(18,19)$.

Type 1 and $\mathrm{P}$ pili expressed by UPEC are considered classical pili, which are heteropolymers of different protein subunits that form rigid, helical rods. Similarly, enterotoxigenic E. coli (ETEC) employs a large group of rigid pili, termed colonization factor antigen (CFA) or coli surface antigen (CS) pili, to adhere to the small intestine, facilitating toxin delivery into the gut lumen (20). Another group of pili assembled by the CU pathway comprises thin, flexible fibers that in some cases form amorphous, capsular-like or 'afimbrial' structures (3). Examples of these are the Afa/Dr pili (21-23), expressed by various pathogenic E. coli strains, and the F1 capsular antigen of Yersinia pestis $(24,25)$, which forms a dense coating around the bacteria and is involved in preventing uptake by macrophages (Fig. 1) $(25,26)$.

CU pili are remarkably adapted to colonization of specific environmental niches. To mediate colonization of the urinary tract, type 1 pili must be able to withstand the shear forces generated by the flow of urine. The FimH adhesin utilizes a catch bond mechanism to switch between low and high affinity binding conformations, facilitating migration (rolling) and receptor sampling in the absence of urinary flow, and attachment (sticking) during periods of turbulence (27-29). The helical pilus rod exhibits properties of compliance and flexibility, which is also important for resistance to shear forces and allows bacteria to regain proximity to host cells after exposure to turbulence (30-32).

\section{Pilus Assembly}

The CU pathway harnesses protein-protein interactions to drive pilus fiber assembly and secretion in the absence of an external energy source such as ATP, which is not available in the bacterial periplasm $(33,34)$. Newly synthesized pilus subunits in the cytoplasm contain an N-terminal signal sequence that directs them to the SecYEG translocon in the inner membrane for translocation into the periplasm (Fig. 2). In the periplasm, the signal sequence is cleaved and the subunits undergo disulfide bond formation in a process catalyzed by the oxidoreductase DsbA $(33,35)$. The subunits then form binary complexes with chaperone 
proteins (FimC for type 1 pili, PapD for P pili). The chaperone only recognizes unfolded subunits that have already undergone disulfide bond formation. This serves an important quality control role, ensuring that only oxidized, mechanically stable subunits are incorporated into the pilus (36-38). The chaperone donates a $\beta$-strand to complete the immunoglobulin-like fold of the subunits in a mechanism termed donor strand complementation (DSC) $(39,40)$. This process allows subunit folding and inhibits premature subunit-subunit interactions. In the absence of the chaperone, subunits misfold, aggregate, and are degraded by the DegP periplasmic protease $(41,42)$.

Periplasmic chaperone-subunit complexes interact with the outer membrane (OM) usher (FimD for type 1 pili, PapC for P pili) (Fig. 2), which catalyzes the exchange of chaperonesubunit for subunit-subunit interactions in a process termed donor strand exchange (DSE) (43-47). In DSE, the N-terminal extension of an incoming pilus subunit displaces the Bstrand donated by the chaperone to release the chaperone and form a subunit-subunit interaction. This interaction is energetically favorable and initiates at a binding pocket on the subunit, termed the P5 pocket, which is left vacant by the chaperone donor strand (43-46). The correct ordering of subunits in the pilus fiber is determined by the differential affinities of chaperone-subunit complexes for the usher and the rate of DSE between different subunitsubunit pairs, as well as the periplasmic concentrations of different subunits (47-51). The usher thus promotes ordered polymerization of the pilus fiber and provides the channel for secretion of the pilus fiber to the cell surface.

The usher comprises a 24-stranded $\beta$-barrel channel domain, a plug domain that serves as a channel gate, an $\mathrm{N}$-terminal periplasmic domain (NTD), and two $\mathrm{C}$ terminal domains (CTD1 and CTD2) (52-55). In the resting (apo) usher, the plug domain occludes the channel pore and masks the usher $\mathrm{C}$ domains $(56,57)$. In the type 1 pilus system, the usher is activated by binding of a FimC-FimH chaperone-adhesin complex to the usher NTD (52). FimC-FimH binding results in plug expulsion from the lumen of the usher channel, which also frees the CTDs $(55,57)$ (Fig. 2). FimC-FimH is then delivered from the usher NTD to the CTDs, in a handover process likely driven by differential affinity and direct domain-domain interactions (57-60). This frees the usher NTD for recruiting the next chaperone-subunit complex (FimC-FimG for type 1 pili) from the periplasm. The newly recruited complex bound to the usher NTD is oriented perfectly to undergo DSE with the previously recruited complex bound at the usher CTDs (55) (Fig. 2). This displaces the chaperone from the subunit bound at the CTDs, forming the first link in the pilus fiber. The newly incorporated chaperonesubunit is then handed over from the usher NTD to the CTDs to reset the system for a new round of subunit recruitment and incorporation, which continues concomitantly with translocation of the nascent pilus fiber through the usher channel to the cell surface. The pilus fiber is thus assembled and secreted in a top-down manner, with the pilus rod adopting its final helical quaternary structure upon exiting the usher pore. The helical rod is stabilized by extensive polar interactions between the pilus rod subunits, providing a remarkable level of flexibility that is important for resistance to shear stress. Shear stress can disrupt these polar interactions, linearizing the pilus rod without breaking the strong hydrophobic interactions that mediate subunit polymerization (61-63). Each of these steps along the CU assembly pathway offers targets for the development of therapeutic inhibitors. 


\section{Pilus-directed Therapeutic Approaches.}

The ever-increasing rate of antibiotic resistance among pathogenic bacteria is necessitating a hard look into alternative methods for treatment $(64,65)$. Anti-virulence therapeutics that specifically target pilus function or assembly represent one such alternative approach to traditional antibiotics. In contrast to traditional antibiotics that non-specifically interfere with essential biological processes, anti-virulence therapeutics disrupt systems only required for bacterial pathogens to cause disease within the host, thus limiting detrimental side effects on commensal bacteria and the selective pressure that leads to antibiotic resistance (66-69).

The indispensable roles that $\mathrm{CU}$ pili play in bacterial pathogenesis make them attractive targets for directed therapeutic intervention. A number of approaches have been taken to develop anti-pilus therapeutics, including vaccines against pilus proteins, inhibitors of pilusmediated adhesion, and small molecules that disrupt pilus biogenesis (Fig. 2). CU pili are prevalent among the Enterobacteriaceae and their structure, function and mechanism of assembly are conserved, suggesting that pilus-targeting therapeutics may have activity against a broad range of bacterial pathogens.

\section{Vaccination strategies.}

Because of their important roles in bacterial virulence, pili have received considerable attention in vaccine development programs. Vaccination with whole pili has proven unsuccessful, mainly due to factors such as phase-variable expression and antigenic variation $(70,71)$. Moreover, in the case of mono-adhesive pili such as type 1 and $\mathrm{P}$ pili, which have a single distal adhesin subunit, this approach may bias the immune system towards structural pilus subunits that are present in much higher copy than the adhesin, thus failing to inhibit pilus function (6). In contrast, vaccination with the adhesin subunit FimH (type 1 pili) or PapG (P pili) confers substantial protection against UPEC in both murine and primate infection models, without affecting the commensal E. coli in the gut (72-76). Vaccination with a truncated form of the mannose-resistant Proteus-like fimbriae (MR/P) tip adhesin $\mathrm{MrpH}$, fused to FliC from Salmonella Typhimurium as an adjuvant, was also found to confer protection against UTI caused by Proteus mirabilis (77). Moreover, in a recent human clinical trial, oral administration of antibodies raised against the colonization factor I (CFA/I) pilus tip adhesin $\mathrm{CfaE}$ conferred substantial protection against ETEC colonization (78).

The catch-bond behavior of pilus adhesins poses some challenges to vaccination. In some cases, antibody binding to FimH stabilizes its high-affinity state and thereby enhances rather than inhibits binding of the adhesin to its receptor (79). Moreover, by shifting from the high to the low-affinity state, FimH may shed bound antibodies (79). Novel approaches have been taken to overcome these issues. For example, a new type of antibody that binds to a single loop within the binding pocket of FimH can displace bound ligand. This parasteric antibody is potent not only in inhibiting but also reversing bacterial adhesion, dissolving surfaceadherent biofilms and conferring protection against cystitis in mice (80). 


\section{Small molecules - receptor analogs.}

For type 1 pili, soluble receptor analogs, termed mannosides, are being developed as antiadhesives by occupying the FimH receptor binding site. Mouse model studies have shown that these compounds can prophylactically prevent bacterial bladder colonization, with efficacy against established UTI as well as catheter-associated UTI (81-84). In a recent study, mannosides were found to selectively deplete intestinal UPEC reservoirs without altering the gut microbiota, which may have implications for reducing the rate of recurrent UTIs (85). Furthermore, by shifting the UPEC niche primarily to the extracellular milieu, mannosides may exhibit synergy with traditional antibiotics (86).

A variety of approaches are being taken to develop mannosides with improved or novel properties. FimH antagonist efficacy has traditionally been evaluated using a truncated FimH construct locked in a single conformation. New approaches taking into consideration the dynamic nature of FimH binding have led to the development of biphenyl mannosides that have excellent affinities for all physiologically relevant FimH conformations and exhibit increased potency compared to conventional FimH antagonists (87). Thiomannosides are reported to have improved metabolic stability and oral bioavailability (88). Galabiose-based soluble receptor analogs are also being developed to target $\mathrm{P}$ pilus adhesion (89). A similar strategy is being employed to develop receptor-mimicking galactosides that target the F9 pilus adhesin FmlH. Lead FmlH antagonists significantly reduce bacterial burdens in the bladders and kidneys of infected mice (90). Thiazolylmannosides and heptylmannoside (HM)-based glycocompounds, a new class of FimH antagonists with greater stability at low $\mathrm{pH}$, have shown efficacy against adherent-invasive E. coli (AIEC), which plays a key role in the gut inflammation of patients with Crohn's disease (91-94). Finally, multivalent inhibitors that function as potent anti-adhesives by cross-linking bacteria have also been developed by coupling FimH antagonists on synthetic scaffolds (95-97).

\section{Small molecules - pilicides.}

Another class of small-molecule $\mathrm{CU}$ pilus inhibitors, known as pilicides, inhibit the pilus assembly and secretion process. The original pilicides consist of molecules with a 2-pyridine scaffold $(98,99)$. These molecules bind to the periplasmic chaperone and interfere with chaperone-subunit interactions or the binding of chaperone-subunit complexes to the usher. These compounds have demonstrated efficacy against pilus-mediated adhesion and biofilm formation (99-101). New synthetic approaches have resulted in the development of new classes of pilicides with improved potency $(102,103)$. In a recent study, pilicide ec240 was found to disrupt assembly of type $1, \mathrm{P}$ and $\mathrm{S}$ pili, as well as flagellar motility. In addition to interfering with pilus assembly, ec240 induces fimS-mediated phase off variation, downregulating type 1 pilus gene expression. Treatment of UPEC with ec240 reduced biofilm formation and bacterial colonization in the mouse UTI model (104).

Computational screening for compounds with complementarity to the FimH P5 binding pocket led to identification of the small-molecule AL1, which inhibits pilus subunit polymerization by disrupting the DSE reaction between the FimH and FimG subunits (105). By disrupting type 1 pilus biogenesis, AL1 reduces biofilm formation and bacterial adhesion to human bladder epithelial cells. Another small-molecule compound, nitazoxanide (NTZ), 
was shown to inhibit biofilm formation by enteroaggregative $E$. coli (EAEC) by disrupting the assembly of AAF CU pili (106). Further analysis demonstrated that NTZ also inhibits type 1 and $P$ pilus assembly via a novel mechanism of action, by interfering with proper folding of the usher protein in the OM (107).

\section{Other approaches.}

A novel approach to target bacterial adhesion is the use of coilicides, a recently developed class of anti-pilus inhibitors that act by impairing compliance of the $\mathrm{CU}$ pilus rod. In a proof-of-principle experiment, it was shown that purified PapD chaperone binds to uncoiled $P$ pilus rods and prevents their recoiling, thus decreasing their ability to withstand shear forces caused by fluid flow (108). Similarly, polyclonal anti-PapA antibodies were found to reduce the elastic properties of P pili (109). Bivalent polyclonal antibodies have also been used to diminish the compliance of CFA/I and coli surface antigen 2 (CS2) pili, which play essential roles in ETEC pathogenesis. These antibodies, which recognize major pilin subunits, decrease pilus resilience during fluid flow by clamping together layers of the helical fiber or two individual pili, thereby increasing their stiffness and entangling them $(110,111)$. The salivary peptide histatin-5 was also found to bind to and stiffen CFA/I pili, inhibiting ETEC colonization in the gastrointestinal tract (112).

Another strategy that is being explored is the engineering of an avirulent asymptomatic bacteriuria (ASB) strain, 83972, to synthesize a surface-located oligosaccharide P pilus receptor mimic. This strain can bind virulent $P$ piliated UPEC, impairing their adhesion to kidney epithelial cells $(113,114)$. In an alternate approach, a recombinant strain 83972 that expresses type 1 pili can interfere with urinary catheter biofilm formation by virulent enterococci (115).

\section{Conclusions}

Pili assembled by the CU pathway function as virulence factors for a range of Gramnegative pathogenic bacteria. Pili are attractive targets for therapeutic intervention, as they are required both for early stages of colonization in the host and maintenance of infection. Therapeutic agents that target CU pili such as vaccines, adhesin receptor analogs, and small molecules show promise in selectively disrupting host-pathogen interactions that are crucial for disease. Such agents offer alternatives to traditional antibiotics and a pathway forward to combat the rising threat of antibiotic resistance. Additional knowledge gained regarding the assembly, structure and function of $\mathrm{CU}$ pili will provide new opportunities for the development of novel anti-infective therapeutics.

\section{ACKNOWLEDGEMENTS}

J.J.P. is supported by Medical Scientist Training Program award T32GM008444 from the US National Institutes of Health (NIH). Research in the Thanassi laboratory on the subject of this review is supported by NIH grants R01GM62987 and R21AI121639.

\section{REFERENCES}

1. Nuccio SP, Baumler AJ. 2007 Evolution of the chaperone/usher assembly pathway: fimbrial classification goes Greek. Microbiol Mol Biol Rev 71:551-575. [PubMed: 18063717] 
2. Zav'yalov V, Zavialov A, Zav'yalova G, Korpela T. 2010 Adhesive organelles of Gram-negative pathogens assembled with the classical chaperone/usher machinery: structure and function from a clinical standpoint. FEMS Microbiol Rev 34:317-378. [PubMed: 20070375]

3. Thanassi DG, Bliska JB, Christie PJ. 2012 Surface organelles assembled by secretion systems of Gram-negative bacteria: diversity in structure and function. FEMS Microbiol Rev 36:1046-1082. [PubMed: 22545799]

4. Geibel S, Waksman G. 2014 The molecular dissection of the chaperone-usher pathway. Biochim Biophys Acta 1843:1559-1567. [PubMed: 24140205]

5. Chahales P, Thanassi DG. 2015 Structure, Function, and Assembly of Adhesive Organelles by Uropathogenic Bacteria. MicrobiolSpectr 5.

6. Werneburg GT, Thanassi DG. 2018 Pili Assembled by the Chaperone/Usher Pathway in Escherichia coli and Salmonella. EcoSal Plus 8.

7. van der Velden AW, Baumler AJ, Tsolis RM, Heffron F. 1998 Multiple fimbrial adhesins are required for full virulence of Salmonella typhimurium in mice. Infect Immun 66:2803-2808. [PubMed: 9596751]

8. Korea CG, Badouraly R, Prevost MC, Ghigo JM, Beloin C. 2010 Escherichia coli K-12 possesses multiple cryptic but functional chaperone-usher fimbriae with distinct surface specificities. Environ Microbiol 12:1957-1977. [PubMed: 20345943]

9. Felek S, Jeong JJ, Runco LM, Murray S, Thanassi DG, Krukonis ES. 2011 Contributions of chaperone/usher systems to cell binding, biofilm formation and Yersinia pestis virulence. Microbiology 157:805-818. [PubMed: 21088108]

10. Wurpel DJ, Beatson SA, Totsika M, Petty NK, Schembri MA. 2013 Chaperone-usher fimbriae of Escherichia coli. PLoS One 8:e52835. [PubMed: 23382825]

11. Roberts JA, Marklund BI, Ilver D, Haslam D, Kaack MB, Baskin G, Louis M, Möllby R, Winberg J, Normark S. 1994 The Gal(alpha 1-4)Gal-specific tip adhesin of Escherichia coli P-fimbriae is needed for pyelonephritis to occur in the normal urinary tract. Proc Natl Acad Sci U S A 91:11889-11893. [PubMed: 7991552]

12. Zhou G, Mo WJ, Sebbel P, Min G, Neubert TA, Glockshuber R, Wu XR, Sun TT, Kong XP. 2001 Uroplakin Ia is the urothelial receptor for uropathogenic Escherichia coli: evidence from in vitro FimH binding. J Cell Sci 114:4095-4103. [PubMed: 11739641]

13. Eto DS, Jones TA, Sundsbak JL, Mulvey MA. 2007 Integrin-mediated host cell invasion by type 1piliated uropathogenic Escherichia coli. PLoS Pathog 7:e100.

14. Mulvey MA, Lopez-Boado YS, Wilson CL, Roth R, Parks WC, Heuser J, Hultgren SJ. 1998 Induction and evasion of host defenses by type 1-piliated uropathogenic Escherichia coli. Science 282:1494-1497. [PubMed: 9822381]

15. Martinez JJ, Mulvey MA, Schilling JD, Pinkner JS, Hultgren SJ. 2000 Type 1 pilus-mediated bacterial invasion of bladder epithelial cells. Embo j 19:2803-2812. [PubMed: 10856226]

16. Pratt LA, Kolter R. 1998 Genetic analysis of Escherichia coli biofilm formation: roles of flagella, motility, chemotaxis and type I pili. Mol Microbiol 30:285-293. [PubMed: 9791174]

17. Wright KJ, Seed PC, Hultgren SJ. 2007 Development of intracellular bacterial communities of uropathogenic Escherichia coli depends on type 1 pili. Cell Microbiol 9:2230-2241. [PubMed: 17490405]

18. Justice SS, Hung C, Theriot JA, Fletcher DA, Anderson GG, Footer MJ, Hultgren SJ. 2004 Differentiation and developmental pathways of uropathogenic Escherichia coli in urinary tract pathogenesis. Proc Natl Acad Sci U S A 101:1333-1338. [PubMed: 14739341]

19. Anderson GG, Palermo JJ, Schilling JD, Roth R, Heuser J, Hultgren SJ. 2003 Intracellular bacterial biofilm-like pods in urinary tract infections. Science 301:105-107. [PubMed: 12843396]

20. Gaastra W, Svennerholm AM. 1996 Colonization factors of human enterotoxigenic Escherichia coli (ETEC). Trends Microbiol 4:444-452. [PubMed: 8950814]

21. Labigne-Roussel A, Schmidt MA, Walz W, Falkow S. 1985 Genetic organization of the afimbrial adhesin operon and nucleotide sequence from a uropathogenic Escherichia coli gene encoding an afimbrial adhesin. J Bacteriol 162:1285-1292. [PubMed: 2860096] 
22. Garcia MI, Gounon P, Courcoux P, Labigne A, Le Bouguenec C. 1996 The afimbrial adhesive sheath encoded by the afa-3 gene cluster of pathogenic Escherichia coli is composed of two adhesins. Mol Microbiol 19:683-693. [PubMed: 8820639]

23. Anderson KL, Billington J, Pettigrew D, Cota E, Simpson P, Roversi P, Chen HA, Urvil P, du Merle L, Barlow PN, Medof ME, Smith RA, Nowicki B, Le Bouguenec C, Lea SM, Matthews S. 2004 An atomic resolution model for assembly, architecture, and function of the Dr adhesins. Mol Cell 15:647-657. [PubMed: 15327779]

24. Titball RW, Howells AM, Oyston PC, Williamson ED. 1997 Expression of the Yersinia pestis capsular antigen (F1 antigen) on the surface of an aroA mutant of Salmonella typhimurium induces high levels of protection against plague. Infect Immun 65:1926-1930. [PubMed: 9125581]

25. Du Y, Rosqvist R, Forsberg A. 2002 Role of fraction 1 antigen of Yersinia pestis in inhibition of phagocytosis. Infect Immun 70:1453-1460. [PubMed: 11854232]

26. Liu F, Chen H, Galvan EM, Lasaro MA, Schifferli DM. 2006 Effects of Psa and F1 on the adhesive and invasive interactions of Yersinia pestis with human respiratory tract epithelial cells. Infect Immun 74:5636-5644. [PubMed: 16988239]

27. Thomas WE, Nilsson LM, Forero M, Sokurenko EV, Vogel V. 2004 Shear-dependent 'stick-androll' adhesion of type 1 fimbriated Escherichia coli. Mol Microbiol 53:1545-1557. [PubMed: 15387828]

28. Le Trong I, Aprikian P, Kidd BA, Forero-Shelton M, Tchesnokova V, Rajagopal P, Rodriguez V, Interlandi G, Klevit R, Vogel V, Stenkamp RE, Sokurenko EV, Thomas WE. 2010 Structural basis for mechanical force regulation of the adhesin FimH via finger trap-like beta sheet twisting. Cell 141:645-655. [PubMed: 20478255]

29. Sauer MM, Jakob RP, Eras J, Baday S, Eriş D, Navarra G, Bernèche S, Ernst B, Maier T, Glockshuber R. 2016 Catch-bond mechanism of the bacterial adhesin FimH. Nature Communications 7:10738.

30. Jass J, Schedin S, Fallman E, Ohlsson J, Nilsson UJ, Uhlin BE, Axner O. 2004 Physical properties of Escherichia coli P pili measured by optical tweezers. Biophys J 87:4271-4283. [PubMed: 15377509]

31. Fallman E, Schedin S, Jass J, Uhlin BE, Axner O. 2005 The unfolding of the P pili quaternary structure by stretching is reversible, not plastic. EMBO Rep 6:52-56. [PubMed: 15592451]

32. Andersson M, Axner O, Almqvist F, Uhlin BE, Fallman E. 2008 Physical properties of biopolymers assessed by optical tweezers: analysis of folding and refolding of bacterial pili. Chemphyschem 9:221-235. [PubMed: 18181116]

33. Jacob-Dubuisson F, Striker R, Hultgren SJ. 1994 Chaperone-assisted self-assembly of pili independent of cellular energy. J Biol Chem 269:12447-12455. [PubMed: 7909802]

34. Thanassi DG, Stathopoulos C, Karkal A, Li H. 2005 Protein secretion in the absence of ATP: the autotransporter, two-partner secretion and chaperone/usher pathways of gram-negative bacteria (review). Mol Membr Biol 22:63-72. [PubMed: 16092525]

35. Totsika M, Heras B, Wurpel DJ, Schembri MA. 2009 Characterization of two homologous disulfide bond systems involved in virulence factor biogenesis in uropathogenic Escherichia coli CFT073. J Bacteriol 191:3901-3908. [PubMed: 19376849]

36. Crespo MD, Puorger C, Scharer MA, Eidam O, Grutter MG, Capitani G, Glockshuber R. 2012 Quality control of disulfide bond formation in pilus subunits by the chaperone FimC. Nat Chem Biol 8:707-713. [PubMed: 22772153]

37. Pilipczuk J, Zalewska-Piatek B, Bruzdziak P, Czub J, Wieczor M, Olszewski M, Wanarska M, Nowicki B, Augustin-Nowacka D, Piatek R. 2017 Role of the disulfide bond in stabilizing and folding of the fimbrial protein DraE from uropathogenic Escherichia coli. J Biol Chem 292:16136-16149. [PubMed: 28739804]

38. Alonso-Caballero A, Schonfelder J, Poly S, Corsetti F, De Sancho D, Artacho E, Perez-Jimenez R. 2018 Mechanical architecture and folding of E. coli type 1 pilus domains. Nat Commun 9:2758. [PubMed: 30013059]

39. Sauer FG, Futterer K, Pinkner JS, Dodson KW, Hultgren SJ, Waksman G. 1999 Structural basis of chaperone function and pilus biogenesis. Science 285:1058-1061. [PubMed: 10446050] 
40. Choudhury D, Thompson A, Stojanoff V, Langermann S, Pinkner J, Hultgren SJ, Knight SD. 1999 $\mathrm{X}$-ray structure of the FimC-FimH chaperone-adhesin complex from uropathogenic Escherichia coli. Science 285:1061-1066. [PubMed: 10446051]

41. Jones CH, Danese PN, Pinkner JS, Silhavy TJ, Hultgren SJ. 1997 The chaperone-assisted membrane release and folding pathway is sensed by two signal transduction systems. Embo j 16:6394-6406. [PubMed: 9351822]

42. Bann JG, Pinkner JS, Frieden C, Hultgren SJ. 2004 Catalysis of protein folding by chaperones in pathogenic bacteria. Proc Natl Acad Sci U S A 101:17389-17393. [PubMed: 15583129]

43. Sauer FG, Pinkner JS, Waksman G, Hultgren SJ. 2002 Chaperone priming of pilus subunits facilitates a topological transition that drives fiber formation. Cell 111:543-551. [PubMed: 12437927]

44. Zavialov AV, Berglund J, Pudney AF, Fooks LJ, Ibrahim TM, MacIntyre S, Knight SD. 2003 Structure and biogenesis of the capsular F1 antigen from Yersinia pestis: preserved folding energy drives fiber formation. Cell 113:587-596. [PubMed: 12787500]

45. Zavialov AV, Tischenko VM, Fooks LJ, Brandsdal BO, Aqvist J, Zav'yalov VP, Macintyre S, Knight SD. 2005 Resolving the energy paradox of chaperone/usher-mediated fibre assembly. Biochem J 389:685-694. [PubMed: 15799718]

46. Remaut H, Rose RJ, Hannan TJ, Hultgren SJ, Radford SE, Ashcroft AE, Waksman G. 2006 Donorstrand exchange in chaperone-assisted pilus assembly proceeds through a concerted beta strand displacement mechanism. Mol Cell 22:831-842. [PubMed: 16793551]

47. Nishiyama M, Ishikawa T, Rechsteiner H, Glockshuber R. 2008 Reconstitution of pilus assembly reveals a bacterial outer membrane catalyst. Science 320:376-379. [PubMed: 18369105]

48. Saulino ET, Thanassi DG, Pinkner JS, Hultgren SJ. 1998 Ramifications of kinetic partitioning on usher-mediated pilus biogenesis. Embo j 17:2177-2185. [PubMed: 9545231]

49. Nishiyama M, Glockshuber R. 2010 The outer membrane usher guarantees the formation of functional pili by selectively catalyzing donor-strand exchange between subunits that are adjacent in the mature pilus. J Mol Biol 396:1-8. [PubMed: 20004668]

50. Li Q, Ng TW, Dodson KW, So SS, Bayle KM, Pinkner JS, Scarlata S, Hultgren SJ, Thanassi DG. 2010 The differential affinity of the usher for chaperone-subunit complexes is required for assembly of complete pili. Mol Microbiol 76:159-172. [PubMed: 20199591]

51. Allen WJ, Phan G, Hultgren SJ, Waksman G. 2013 Dissection of pilus tip assembly by the FimD usher monomer. J Mol Biol 425:958-967. [PubMed: 23295826]

52. Nishiyama M, Horst R, Eidam O, Herrmann T, Ignatov O, Vetsch M, Bettendorff P, Jelesarov I, Grutter MG, Wuthrich K, Glockshuber R, Capitani G. 2005 Structural basis of chaperone-subunit complex recognition by the type 1 pilus assembly platform FimD. Embo j 24:2075-2086. [PubMed: 15920478]

53. Remaut H, Tang C, Henderson NS, Pinkner JS, Wang T, Hultgren SJ, Thanassi DG, Waksman G, Li H. 2008 Fiber formation across the bacterial outer membrane by the chaperone/usher pathway. Cell 133:640-652. [PubMed: 18485872]

54. Huang Y, Smith BS, Chen LX, Baxter RH, Deisenhofer J. 2009 Insights into pilus assembly and secretion from the structure and functional characterization of usher PapC. Proc Natl Acad Sci U S A 106:7403-7407. [PubMed: 19380723]

55. Phan G, Remaut H, Wang T, Allen WJ, Pirker KF, Lebedev A, Henderson NS, Geibel S, Volkan E, Yan J, Kunze MB, Pinkner JS, Ford B, Kay CW, Li H, Hultgren SJ, Thanassi DG, Waksman G. 2011 Crystal structure of the FimD usher bound to its cognate FimC-FimH substrate. Nature 474:49-53. [PubMed: 21637253]

56. Mapingire OS, Henderson NS, Duret G, Thanassi DG, Delcour AH. 2009 Modulating effects of the plug, helix, and N- and C-terminal domains on channel properties of the PapC usher. J Biol Chem 284:36324-36333. [PubMed: 19850919]

57. Werneburg GT, Henderson NS, Portnoy EB, Sarowar S, Hultgren SJ, Li H, Thanassi DG. 2015 The pilus usher controls protein interactions via domain masking and is functional as an oligomer. Nat Struct Mol Biol 22:540-546. [PubMed: 26052892] 
58. Volkan E, Ford BA, Pinkner JS, Dodson KW, Henderson NS, Thanassi DG, Waksman G, Hultgren SJ. 2012 Domain activities of PapC usher reveal the mechanism of action of an Escherichia coli molecular machine. Proc Natl Acad Sci U S A 109:9563-9568. [PubMed: 22645361]

59. Omattage NS, Deng Z, Pinkner JS, Dodson KW, Almqvist F, Yuan P, Hultgren SJ. 2018 Structural basis for usher activation and intramolecular subunit transfer in $\mathrm{P}$ pilus biogenesis in Escherichia coli. Nat Microbiol 3:1362-1368. [PubMed: 30275511]

60. Du M, Yuan Z, Yu H, Henderson N, Sarowar S, Zhao G, Werneburg GT, Thanassi DG, Li H. 2018 Handover mechanism of the growing pilus by the bacterial outer-membrane usher FimD. Nature 562:444-447. [PubMed: 30283140]

61. Hospenthal MK, Zyla D, Costa TRD, Redzej A, Giese C, Lillington J, Glockshuber R, Waksman G. 2017 The Cryoelectron Microscopy Structure of the Type 1 Chaperone-Usher Pilus Rod. Structure 25:1829-1838 e1824. [PubMed: 29129382]

62. Hospenthal MK, Redzej A, Dodson K, Ukleja M, Frenz B, Rodrigues C, Hultgren SJ, DiMaio F, Egelman EH, Waksman G. 2016 Structure of a Chaperone-Usher Pilus Reveals the Molecular Basis of Rod Uncoiling. Cell 164:269-278. [PubMed: 26724865]

63. Spaulding CN, Schreiber HLt, Zheng W, Dodson KW, Hazen JE, Conover MS, Wang F, Svenmarker P, Luna-Rico A, Francetic O, Andersson M, Hultgren S, Egelman EH. 2018 Functional role of the type 1 pilus rod structure in mediating host-pathogen interactions. Elife 7.

64. Fauci AS, Morens DM. 2012 The perpetual challenge of infectious diseases. N Engl J Med 366:454-461. [PubMed: 22296079]

65. World Health Organization. 2014 Antimicrobial Resistance: Global Report on Surveillance. WHO Press.

66. Cegelski L, Marshall GR, Eldridge GR, Hultgren SJ. 2008 The biology and future prospects of antivirulence therapies. Nat Rev Microbiol 6:17-27. [PubMed: 18079741]

67. Allen RC, Popat R, Diggle SP, Brown SP. 2014 Targeting virulence: can we make evolution-proof drugs? Nat Rev Microbiol 12:300-308. [PubMed: 24625893]

68. Zambelloni R, Marquez R, Roe AJ. 2015 Development of antivirulence compounds: a biochemical review. Chem Biol Drug Des 85:43-55. [PubMed: 25521644]

69. Paharik AE, Schreiber HLt, Spaulding CN, Dodson KW, Hultgren SJ. 2017 Narrowing the spectrum: the new frontier of precision antimicrobials. Genome Med 9:110. [PubMed: 29241446]

70. Svennerholm AM, Tobias J. 2008 Vaccines against enterotoxigenic Escherichia coli. Expert Rev Vaccines 7:795-804. [PubMed: 18665777]

71. van der Woude MW, Baumler AJ. 2004 Phase and antigenic variation in bacteria. Clin Microbiol Rev 17:581-611. [PubMed: 15258095]

72. Langermann S, Palaszynski S, Barnhart M, Auguste G, Pinkner JS, Burlein J, Barren P, Koenig S, Leath S, Jones CH, Hultgren SJ. 1997 Prevention of mucosal Escherichia coli infection by FimHadhesin-based systemic vaccination. Science 276:607-611. [PubMed: 9110982]

73. Thankavel K, Madison B, Ikeda T, Malaviya R, Shah AH, Arumugam PM, Abraham SN. 1997 Localization of a domain in the FimH adhesin of Escherichia coli type 1 fimbriae capable of receptor recognition and use of a domain-specific antibody to confer protection against experimental urinary tract infection. J Clin Invest 100:1123-1136. [PubMed: 9276729]

74. Langermann S, Mollby R, Burlein JE, Palaszynski SR, Auguste CG, DeFusco A, Strouse R, Schenerman MA, Hultgren SJ, Pinkner JS, Winberg J, Guldevall L, Soderhall M, Ishikawa K, Normark S, Koenig S. 2000 Vaccination with FimH adhesin protects cynomolgus monkeys from colonization and infection by uropathogenic Escherichia coli. J Infect Dis 181:774-778. [PubMed: 10669375]

75. Roberts JA, Kaack MB, Baskin G, Chapman MR, Hunstad DA, Pinkner JS, Hultgren SJ. 2004 Antibody responses and protection from pyelonephritis following vaccination with purified Escherichia coli PapDG protein. J Urol 171:1682-1685. [PubMed: 15017266]

76. Poggio TV, La Torre JL, Scodeller EA. 2006 Intranasal immunization with a recombinant truncated FimH adhesin adjuvanted with $\mathrm{CpG}$ oligodeoxynucleotides protects mice against uropathogenic Escherichia coli challenge. Can J Microbiol 52:1093-1102. [PubMed: 17215901] 
77. Bameri Z, Asadi Karam MR, Habibi M, Ehsani P, Bouzari S. 2018 Determination immunogenic property of truncated MrpH.FliC as a vaccine candidate against urinary tract infections caused by Proteus mirabilis. Microb Pathog 114:99-106. [PubMed: 29138084]

78. Savarino SJ, McKenzie R, Tribble DR, Porter CK, O’Dowd A, Cantrell JA, Sincock SA, Poole ST, DeNearing B, Woods CM, Kim H, Grahek SL, Brinkley C, Crabb JH, Bourgeois AL. 2017 Prophylactic Efficacy of Hyperimmune Bovine Colostral Antiadhesin Antibodies Against Enterotoxigenic Escherichia coli Diarrhea: A Randomized, Double-Blind, Placebo-Controlled, Phase 1 Trial. J Infect Dis 216:7-13. [PubMed: 28541500]

79. Tchesnokova V, Aprikian P, Kisiela D, Gowey S, Korotkova N, Thomas W, Sokurenko E. 2011 Type 1 Fimbrial Adhesin FimH Elicits an Immune Response That Enhances Cell Adhesion of Escherichia coli. Infect Immun 10:3895-3904.

80. Kisiela DI, Avagyan H, Friend D, Jalan A, Gupta S, Interlandi G, Liu Y, Tchesnokova V, Rodriguez VB, Sumida JP, Strong RK, Wu XR, Thomas WE, Sokurenko EV. 2015 Inhibition and Reversal of Microbial Attachment by an Antibody with Parasteric Activity against the FimH Adhesin of Uropathogenic E. coli. PLoS Pathog 11:e1004857. [PubMed: 25974133]

81. Klein T, Abgottspon D, Wittwer M, Rabbani S, Herold J, Jiang X, Kleeb S, Luthi C, Scharenberg M, Bezencon J, Gubler E, Pang L, Smiesko M, Cutting B, Schwardt O, Ernst B. 2010 FimH antagonists for the oral treatment of urinary tract infections: from design and synthesis to in vitro and in vivo evaluation. J Med Chem 53:8627-8641. [PubMed: 21105658]

82. Cusumano CK, Pinkner JS, Han Z, Greene SE, Ford BA, Crowley JR, Henderson JP, Janetka JW, Hultgren SJ. 2011 Treatment and Prevention of Urinary Tract Infection with Orally Active FimH Inhibitors. Sci Transl Med 3:109ra115.

83. Jiang X, Abgottspon D, Kleeb S, Rabbani S, Scharenberg M, Wittwer M, Haug M, Schwardt O, Ernst B. 2012 Antiadhesion therapy for urinary tract infections--a balanced PK/PD profile proved to be key for success. J Med Chem 55:4700-4713. [PubMed: 22519985]

84. Totsika M, Kostakioti M, Hannan TJ, Upton M, Beatson SA, Janetka JW, Hultgren SJ, Schembri MA. 2013 A FimH inhibitor prevents acute bladder infection and treats chronic cystitis caused by multidrug-resistant uropathogenic Escherichia coli ST131. J Infect Dis 208:921-928. [PubMed: 23737602]

85. Spaulding CN, Klein RD, Ruer S, Kau AL, Schreiber HL, Cusumano ZT, Dodson KW, Pinkner JS, Fremont DH, Janetka JW, Remaut H, Gordon JI, Hultgren SJ. 2017 Selective depletion of uropathogenic E. coli from the gut by a FimH antagonist. Nature 546:528-532. [PubMed: 28614296]

86. Guiton PS, Cusumano CK, Kline KA, Dodson KW, Han Z, Janetka JW, Henderson JP, Caparon MG, Hultgren SJ. 2012 Combinatorial small-molecule therapy prevents uropathogenic Escherichia coli catheter-associated urinary tract infections in mice. Antimicrob Agents Chemother 56:47384745. [PubMed: 22733070]

87. Mayer K, Eris D, Schwardt O, Sager CP, Rabbani S, Kleeb S, Ernst B. 2017 Urinary Tract Infection: Which Conformation of the Bacterial Lectin FimH Is Therapeutically Relevant? J Med Chem 60:5646-5662. [PubMed: 28471659]

88. Sattigeri JA, Garg M, Bhateja P, Soni A, Rauf ARA, Gupta M, Deshmukh MS, Jain T, Alekar N, Barman TK, Jha P, Chaira T, Bambal RB, Upadhyay DJ, Nishi T. 2018 Synthesis and evaluation of thiomannosides, potent and orally active FimH inhibitors. Bioorg Med Chem Lett 28:2993-2997. [PubMed: 30017316]

89. Salminen A, Loimaranta V, Joosten JA, Khan AS, Hacker J, Pieters RJ, Finne J. 2007 Inhibition of P-fimbriated Escherichia coli adhesion by multivalent galabiose derivatives studied by a livebacteria application of surface plasmon resonance. J Antimicrob Chemother 60:495-501. [PubMed: 17623698]

90. Kalas V, Hibbing ME, Maddirala AR, Chugani R, Pinkner JS, Mydock-McGrane LK, Conover MS, Janetka JW, Hultgren SJ. 2018 Structure-based discovery of glycomimetic FmlH ligands as inhibitors of bacterial adhesion during urinary tract infection. Proc Natl Acad Sci U S A 115:E2819-e2828. [PubMed: 29507247]

91. Brument S, Sivignon A, Dumych TI, Moreau N, Roos G, Guerardel Y, Chalopin T, Deniaud D, Bilyy RO, Darfeuille-Michaud A, Bouckaert J, Gouin SG. 2013 Thiazolylaminomannosides as 
potent antiadhesives of type 1 piliated Escherichia coli isolated from Crohn's disease patients. J Med Chem 56:5395-5406. [PubMed: 23795713]

92. Sivignon A, Yan X, Alvarez Dorta D, Bonnet R, Bouckaert J, Fleury E, Bernard J, Gouin SG, Darfeuille-Michaud A, Barnich N. 2015 Development of Heptylmannoside-Based Glycoconjugate Antiadhesive Compounds against Adherent-Invasive Escherichia coli Bacteria Associated with Crohn's Disease. MBio 6:e01298-01215. [PubMed: 26578673]

93. Chalopin T, Alvarez Dorta D, Sivignon A, Caudan M, Dumych TI, Bilyy RO, Deniaud D, Barnich N, Bouckaert J, Gouin SG. 2016 Second generation of thiazolylmannosides, FimH antagonists for E. coli-induced Crohn's disease. Org Biomol Chem 14:3913-3925. [PubMed: 27043998]

94. Sivignon A, Bouckaert J, Bernard J, Gouin SG, Barnich N. 2017 The potential of FimH as a novel therapeutic target for the treatment of Crohn's disease. Expert Opin Ther Targets 21:837-847. [PubMed: 28762293]

95. Almant M, Moreau V, Kovensky J, Bouckaert J, Gouin SG. 2011 Clustering of Escherichia coli type-1 fimbrial adhesins by using multimeric heptyl alpha-D-mannoside probes with a carbohydrate core. Chemistry 17:10029-10038. [PubMed: 21774001]

96. Schierholt A, Hartmann M, Lindhorst TK. 2011 Bi- and trivalent glycopeptide mannopyranosides as inhibitors of type 1 fimbriae-mediated bacterial adhesion: variation of valency, aglycon and scaffolding. Carbohydr Res 346:1519-1526. [PubMed: 21645881]

97. Richards SJ, Jones MW, Hunaban M, Haddleton DM, Gibson MI. 2012 Probing bacterial-toxin inhibition with synthetic glycopolymers prepared by tandem postpolymerization modification: role of linker length and carbohydrate density. Angew Chem Int Ed Engl 51:7812-7816. [PubMed: 22715146]

98. Svensson A, Larsson A, Emtenas H, Hedenstrom M, Fex T, Hultgren SJ, Pinkner JS, Almqvist F, Kihlberg J. 2001 Design and evaluation of pilicides: potential novel antibacterial agents directed against uropathogenic Escherichia coli. Chembiochem 2:915-918. [PubMed: 11948880]

99. Pinkner JS, Remaut H, Buelens F, Miller E, Aberg V, Pemberton N, Hedenstrom M, Larsson A, Seed P, Waksman G, Hultgren SJ, Almqvist F. 2006 Rationally designed small compounds inhibit pilus biogenesis in uropathogenic bacteria. Proc Natl Acad Sci U S A 103:17897-17902. [PubMed: 17098869]

100. Chorell E, Pinkner JS, Bengtsson C, Banchelin TS, Edvinsson S, Linusson A, Hultgren SJ, Almqvist F. 2012 Mapping pilicide anti-virulence effect in Escherichia coli, a comprehensive structure-activity study. Bioorg Med Chem 20:3128-3142. [PubMed: 22464688]

101. Piatek R, Zalewska-Piatek B, Dzierzbicka K, Makowiec S, Pilipczuk J, Szemiako K, CyrankaCzaja A, Wojciechowski M. 2013 Pilicides inhibit the FGL chaperone/usher assisted biogenesis of the Dr fimbrial polyadhesin from uropathogenic Escherichia coli. BMC Microbiol 13:131. [PubMed: 23758700]

102. Chorell E, Pinkner JS, Phan G, Edvinsson S, Buelens F, Remaut H, Waksman G, Hultgren SJ, Almqvist F. 2010 Design and Synthesis of C-2 Substituted Thiazolo and Dihydrothiazolo RingFused 2-Pyridones: Pilicides with Increased Antivirulence Activity. J Med Chem 53:5690-5695. [PubMed: 20586493]

103. Dang HT, Chorell E, Uvell H, Pinkner JS, Hultgren SJ, Almqvist F. 2014 Syntheses and biological evaluation of 2-amino-3-acyl-tetrahydrobenzothiophene derivatives; antibacterial agents with antivirulence activity. Org Biomol Chem 12:1942-1956. [PubMed: 24531242]

104. Greene SE, Pinkner JS, Chorell E, Dodson KW, Shaffer CL, Conover MS, Livny J, Hadjifrangiskou M, Almqvist F, Hultgren SJ. 2014 Pilicide ec240 Disrupts Virulence Circuits in Uropathogenic Escherichia coli, mBio 5:e02038. [PubMed: 25352623]

105. Lo AW, Van de Water K, Gane PJ, Chan AW, Steadman D, Stevens K, Selwood DL, Waksman G, Remaut H. 2014 Suppression of type 1 pilus assembly in uropathogenic Escherichia coli by chemical inhibition of subunit polymerization. J Antimicrob Chemother 69:1017-1026. [PubMed: 24324225]

106. Shamir ER, Warthan M, Brown SP, Nataro JP, Guerrant RL, Hoffman PS. 2010 Nitazoxanide Inhibits Biofilm Production and Hemagglutination by Enteroaggregative Escherichia coli Strains by Blocking Assembly of AafA Fimbriae. Antimicrob Agents Chemother 54:1526-1533. [PubMed: 20086145] 
107. Chahales P, Hoffman PS, Thanassi DG. 2016 Nitazoxanide Inhibits Pilus Biogenesis by Interfering with Folding of the Usher Protein in the Outer Membrane. Antimicrob Agents Chemother 60:2028-2038. [PubMed: 26824945]

108. Klinth JE, Pinkner JS, Hultgren SJ, Almqvist F, Uhlin BE, Axner O. 2012 Impairment of the biomechanical compliance of $\mathrm{P}$ pili: a novel means of inhibiting uropathogenic bacterial infections? Eur Biophys J 41:285-295. [PubMed: 22237603]

109. Mortezaei N, Singh B, Bullitt E, Uhlin BE, Andersson M. 2013 P-fimbriae in the presence of anti-PapA antibodies: new insight of antibodies action against pathogens. Sci Rep 3:3393. [PubMed: 24292100]

110. Singh B, Mortezaei N, Uhlin BE, Savarino SJ, Bullitt E, Andersson M. 2015 Antibody-mediated disruption of the mechanics of CS20 fimbriae of enterotoxigenic Escherichia coli. Sci Rep 5:13678. [PubMed: 26411657]

111. Singh B, Mortezaei N, Savarino SJ, Uhlin BE, Bullitt E, Andersson M. 2017 Antibodies Damage the Resilience of Fimbriae, Causing Them To Be Stiff and Tangled. J Bacteriol 199.

112. Brown JW, Badahdah A, Iticovici M, Vickers TJ, Alvarado DM, Helmerhorst EJ, Oppenheim FG, Mills JC, Ciorba MA, Fleckenstein JM, Bullitt E. 2018 A Role for Salivary Peptides in the Innate Defense Against Enterotoxigenic Escherichia coli. J Infect Dis 217:1435-1441. [PubMed: 29528423]

113. Paton AW, Morona R, Paton JC. 2000 A new biological agent for treatment of Shiga toxigenic Escherichia coli infections and dysentery in humans. Nat Med 6:265-270. [PubMed: 10700227]

114. Watts RE, Tan CK, Ulett GC, Carey AJ, Totsika M, Idris A, Paton AW, Morona R, Paton JC, Schembri MA. 2012 Escherichia coli 83972 expressing a P fimbriae oligosaccharide receptor mimic impairs adhesion of uropathogenic E. coli. J Infect Dis 206:1242-1249. [PubMed: 22872729]

115. Trautner BW, Cevallos ME, Li H, Riosa S, Hull RA, Hull SI, Tweardy DJ, Darouiche RO.2008 Increased expression of type-1 fimbriae by nonpathogenic Escherichia coli 83972 results in an increased capacity for catheter adherence and bacterial interference. J Infect Dis 198:899-906. [PubMed: 18643750] 
A
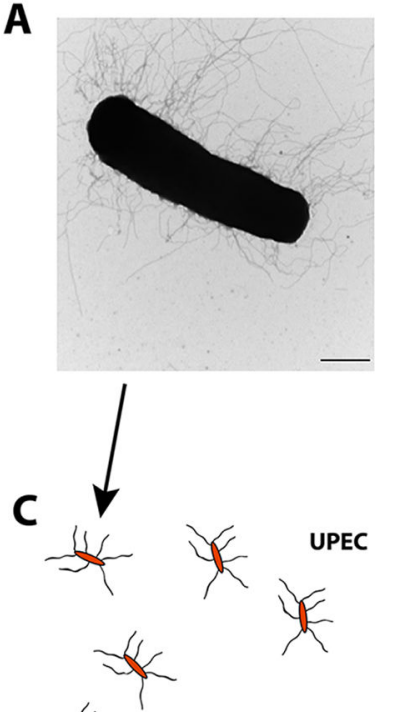

B

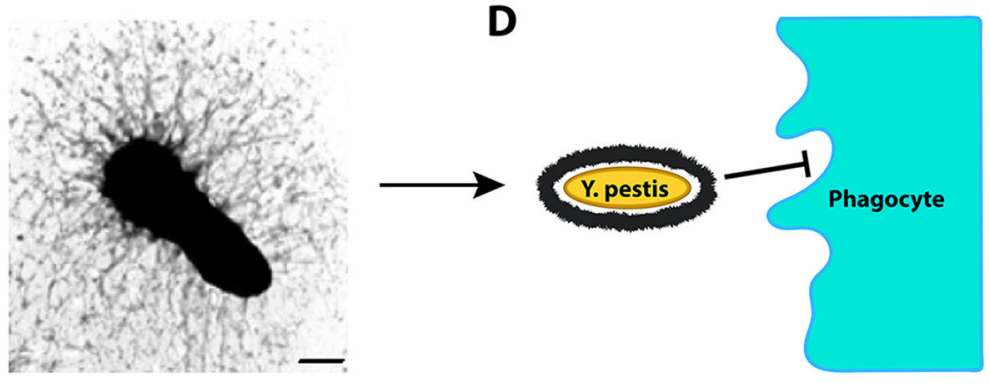

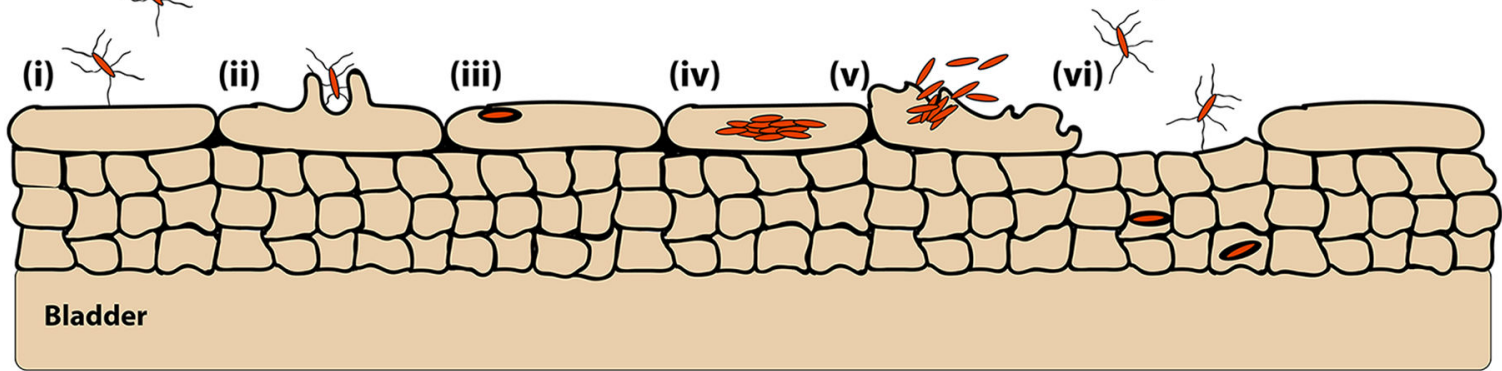

Figure 1. Ultrastructure and function of $\mathrm{CU}$ pili.

Electron micrographs of (A) E. coli expressing type 1 pili and (B) Y. pestis expressing F1 capsule. Scale bars $=500 \mathrm{~nm}$. (C) Cartoon for pilus-mediated bacterial interactions in the bladder. (i) Type 1-piliated UPEC binds to superficial umbrella cells that line the lumen of the bladder. (ii) Pilus-receptor interactions induce a signaling cascade that promotes internalization of adherent bacteria via a membrane zippering mechanism. (iii) Within bladder epithelial cells, UPEC are trafficked to membrane-bound, acidic compartments similar to lysosomes. (iv) In the superficial umbrella cells, UPEC break into the cytosol and rapidly multiply, forming intracellular biofilm-like communities. (v) Bladder cells containing large numbers of UPEC exfoliate, providing a mechanism for bacterial clearance by the flow of urine. (vi) This, however, leaves the underlying layers of immature bladder epithelial cells exposed. UPEC can invade these immature urothelial cells and persist in a quiescent stage in late endosome-like compartments, avoiding detection by immunosurveillance mechanisms. (D) The Y. pestis F1 capsule serves an anti-phagocytic role by preventing opsonizing antibodies from binding to the bacterial surface, blocking Fc receptor phagocytosis. More generally, expression of the F1 capsule can mask bacterial adhesins and other surface structures, preventing interactions that lead to internalization into host cells. 


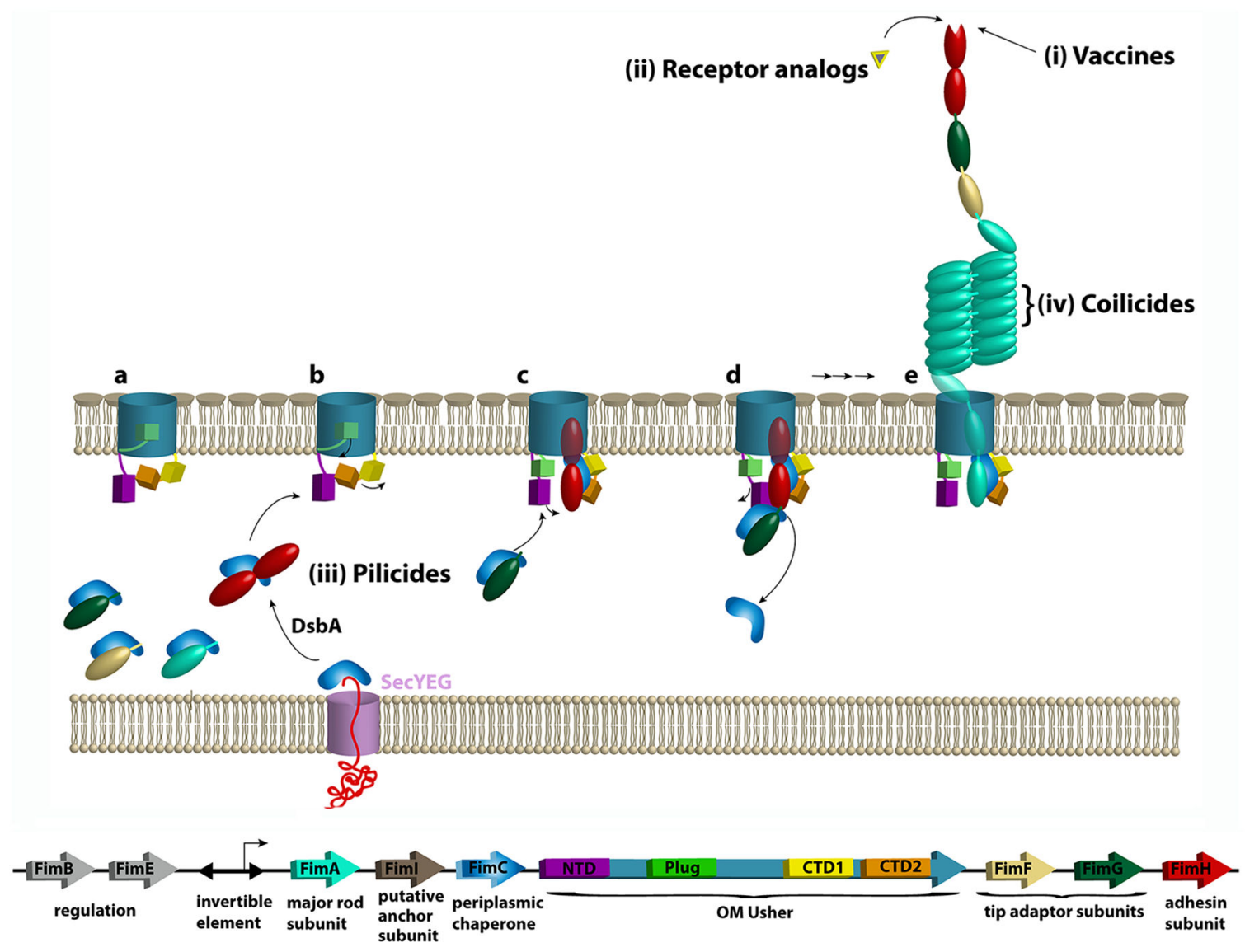

Figure 2. CU pilus assembly pathway and targets for therapeutic intervention.

The fim gene cluster coding for type 1 pili, along with names and functions of encoded proteins, is shown at the bottom. Upon entering the periplasm via the SecYEG general secretory machinery, nascent pilus subunits form binary complexes with the pilus chaperone (FimC), which facilitates subunit folding by DSC, completing the Ig fold of the subunit's pilin domain. The adhesin subunit (FimH, red) is depicted with an additional N-terminal lectin domain, which contains the receptor-binding site. Chaperone-subunit complexes then interact with the OM usher (FimD), which comprises a $\beta$-barrel channel domain, a plug domain, an N-terminal periplasmic domain (NTD), and two $\mathrm{C}$ terminal domains (CTD1 and CTD2). (a) In the resting usher, the plug domain occludes the channel pore and masks the CTDs. (b-c) The usher is activated by binding of a FimC-FimH chaperone-adhesin complex to the usher NTD. This results in displacement of the plug from the channel and handoff of FimC-FimH to the usher CTDs, freeing the NTD to recruit the next chaperone-subunit complex (FimC-FimG). (d) The newly recruited complex bound to the NTD is oriented perfectly to undergo DSE with the previously recruited complex bound to the CTDs, forming the first link in the pilus fiber. The newly incorporated chaperone-subunit is then handed over from the NTD to the CTDs. (e) Repeated rounds of this process result in assembly and secretion of the pilus fiber. Different steps along this pathway are targets for anti-pilus therapeutics. (i) Vaccination using a full-length or truncated adhesin subunit inhibits pilus-mediated bacterial adhesion and pathogenesis. (ii) Small molecule receptor analogs occupy the pilus adhesin binding site, preventing pili from adhering to host 
receptors. (iii) Pilicides inhibit pilus assembly via different mechanisms, such as interfering with chaperone-subunit or subunit-subunit interactions, interfering with binding of chaperone-subunit complexes to the usher, or inhibiting proper folding of the usher in the bacterial OM. (iv) Coilicides inhibit uncoiling and recoiling of the pilus rod, thus impairing resilience of the fibers during fluid flow. 